\title{
Nahón, Abraham (2017). Imágenes en OAXaca. Arte, Política y memoria. Jalisco: Ciesas, Universidad de Guadalajara, Cátedra Jorge Alonso
}

\author{
Adolfo Colombres
}

\section{Una investigación y aporte crítico sobre las imágenes en Oaxaca}

S i bien la obra Imágenes en Oaxaca. Arte, política y memoria de Abraham Nahón — premiada en 2015 por la Cátedra Jorge Alonso del CIESAS y la Universidad de Guadalajara- se trata de una tesis académica, logra trascender dicho campo, ocultando su rigor en la forma de un ensayo que reivindica el derecho de pensar libremente, sin el paraguas de autores reconocidos. Articula así un pensamiento situado en el emblemático territorio oaxaqueño, aunque no para quedarse en él, sino para iluminar con sus aportes teóricos y sus imágenes artísticas, estrechamente relacionadas con la política y la historia, el escenario nacional. Porque bien le hace a esas luces que vienen de afuera, postuladas por este solo hecho como universales, dialogar con las caras de un adentro que cuentan con numerosos siglos de enfrentarse con el desafío de las formas y, al menos, medio milenio de un resistido colonialismo simbólico. El ardor de este pasado nada idílico permite al autor situarse con fuerza en las escenografías urbanas - también en las rurales (ese interior del interior) - y criticar sin atenuantes la visión edénica que se construyó sobre Oaxaca, así como la corriente sustancialista que durante décadas petrificó la identidad cultural de dicho territorio, hasta convertirlo en una parodia de sí mismo, como lo muestra el fenómeno de la guelaguetza.

Desde el mismo nacimiento del mercado del arte en la ciudad se manifestó el conflicto entre el tipicismo folklorista, las corrientes europeas y las imágenes de la resistencia a todas las formas de dominación, las que fueron duramente combatidas desde el gran arraigo de una tradición que supo renovarse y proyectarse no sólo a nivel nacional, sino también, y con especial éxito, al internacional, plano que se potenció primero con Rufino Tamayo y luego con Francisco Toledo, Rodolfo Morales, Rubén Leyva y Alejandro Santiago, entre otros artistas, tal como se analiza en esta investigación. Oaxaca atrajo así tanto o más a los especialistas del arte que la producción plástica de la Ciudad de México. Se observa esto último en el capítulo II de la obra, que aborda el proceso que va del movimiento muralista a Tamayo, ocupándose de Diego Rivera, José Clemente Orozco y David Alfaro Siqueiros. Analiza el autor los murales conflictivos de Orozco, cuyo exceso de dolor lo lleva a vincularlo con la estética expresionista europea, imágenes patéticas de la guerra y el sufrimiento que arrojan una visión un tanto apocalíptica del mundo. El muralismo le permite al autor mirar de manera crítica el movimiento cultural y artístico actual, al hallar

Adolfo Colombres. Investigador independiente. Argentina. Correo electrónico: aarcolombres@gmail.com. 
vínculos y resonancias históricas en el despliegue de este arte social.

Más se detiene Nahón en Siqueiros, destacando la importancia que tuvo su encuentro con Eisenstein, pues la técnica de montaje de este genial cineasta ruso lo llevó a multiplicar los puntos de perspectiva, quebrando así el punto de vista único propio del espacio renacentista, a la vez que avanzaba en la integración entre arquitectura, pintura y escultura. Siqueiros - refiere el autor — llegó a utilizar una cámara de cine para reproducir la visión de un espectador en movimiento y ajustar con mayor eficacia la composición de sus obras. O sea, crea en la pintura una mirada dinámica, plasmando algo así como un muralismo cinético. En el taller experimental que realiza en Nueva York, Siqueiros instaura prácticas de improvisación a las que llama "accidentes pictóricos", como el goteo de pintura sobre la tela y la elaboración de texturas con arena, recursos que serían tomados luego por los jóvenes artistas norteamericanos que desarrollarían el expresionismo abstracto, siendo su discípulo Jackson Pollock el más destacado de ellos.

En cuanto a Rufino Tamayo - acaso el mayor plástico que dio Oaxaca en el siglo XX, junto con Francisco Toledo-, destaca Nahón su negativa a aceptar el predominio del aspecto temático en la pintura mural, sosteniendo la primacía de la calidad plástica, con lo que relativiza la función social que dio nacimiento a esta corriente artística. Le reconoce asimismo el haber incorporado la mixografía, técnica de impresión que permite producir grabados tridimensionales. Además de reconocer en Tamayo no sólo la influencia del arte precolombino y la dimensión cultural que desde los pueblos originarios ilumina su obra, sino su apoyo a otros artistas oaxaqueños - como Francisco Toledo, Rodolfo Morales y Rodolfo Nieto- y sus aportes filantrópicos en la entidad, ejemplo que sería seguido por otros artistas.

Como no podía ser de otro modo, el libro aborda el espinoso tema de las industrias culturales. Invoca a Adorno y Horkheimer, quienes ya percibieron en su tiempo que la esencia del arte estaba siendo absorbida por ellas, al situarlo en un nivel similar al entretenimiento que ofrece la radio y la televisión. Cayó así en la esfera del consumo, pues se vende como un producto más, con lo que pierde su capacidad de conmover al receptor. Claro que hay obras que logran sustraerse a esta degradación, alejando con su obstinada resistencia a quienes se acercan a ellas para "consumirlas". Además, analiza y dialoga con una constelación de pensadores a la par de investigaciones sociológicas, históricas y antropológicas realizadas sobre Oaxaca.

Uno de los artistas que ocupa un lugar importante en esta publicación es Francisco Toledo, tanto por su obra artística como por sus aportes en lo social. De familia juchiteca, se reconoce como zapoteca del Istmo. Con la primera alcanzó pronto una gran repercusión internacional, y en lo segundo sobresale la creación del Instituto de Artes Gráficas de Oaxaca (IAGO), inaugurado en 1988, con el apoyo del gobierno estatal y el INBA. Su biblioteca especializada en arte está entre las más ricas de América Latina. Cabe destacar asimismo su constante afán de promover a los jóvenes artistas indígenas, formando una escuela que abrió el camino a una modernidad propia o paralela en el estado de Oaxaca. Toledo es también un artista que cuestionó radicalmente la colonización simbólica del cristianismo de los pueblos originarios de su tierra y del país.

Destaca Nahón el papel que tuvo la irrupción del movimiento popular de 2006 en el incremento del grafiti, el que pasó a ser el sustrato de la gráfica contemporánea, de la que él es acaso el mayor propulsor. Esta obra se ocupa de los artistas y colectivos gráficos del estado, así como de los cruces culturales, políticos y estéticos de sus obras. Pone asimismo en relieve la dimensión sociocultural de la fotografía en Oaxaca y su contribución a una memoria social, que siempre está en disputa. Horizonte visual que se inicia con los viajeros, exploradores y fotógrafos del siglo XIX, y sigue con las imágenes de la Revolución mexicana. Toma luego a Manuel Álvarez Bravo, mostrando el despliegue de los lenguajes fotográficos que se dieron a partir de la obra de este gran artista, los que terminaron de conformar una verdadera cultura visual y una memoria social. En 2006, las fotografías son relevantes para la construcción de historias a contrapelo de la historia oficial. 
El autor atribuye la ausencia de un pensamiento crítico en Oaxaca a un fracaso educativo, algo que se viene subsanando últimamente, pero también potenciando, desde mi punto de vista, especialmente por iniciativas independientes y artísticas como la revista Luna Zeta, que él mismo publica desde hace diecinueve años con gran esfuerzo. Este investigador oaxaqueño — que actualmente aborda la temática del arte y la fotografía desde el Instituto de Investigaciones en Humanidades de la Universidad Autónoma Benito Juárez de Oaxaca- concluye su estudio afirmando que la disputa por la memoria es una batalla que debe también darse en el campo de las imágenes, las que entrecruzan, proponen o despliegan un trabajo documental y artístico nutrido con la fuerza de lo político, una afirmación de lo propio que ha de leerse como una resistencia a la destrucción del tejido de la cultura por la sacralización del consumo. 